\title{
Bromocriptine, a Dopamine Agonist, Increases Growth Hormone Secretion in a Patient with Acromegaly
}

\author{
Zenei Arihara, ${ }^{1}$ Kanako Sakurai, ${ }^{1}$ Rika Yamashita, ${ }^{1}$ Satsuki Niitsuma, ${ }^{1}$ \\ Takayuki Ueno, ${ }^{1}$ Nao Yamamura, ${ }^{1,2}$ Shozo Yamada, ${ }^{3}$ Naoko Inoshita ${ }^{4}$ and \\ Kazuhiro Takahashi \\ ${ }^{1}$ Department of Endocrinology and Metabolism, Sendai Medical Center, Sendai, Miyagi, Japan \\ ${ }^{2}$ Department of Endocrinology and Applied Medical Science, Tohoku University Graduate School of Medicine, \\ Sendai, Miyagi, Japan \\ ${ }^{3}$ Department of Hypothalamic and Pituitary Surgery, Toranomon Hospital, Tokyo, Japan \\ ${ }^{4}$ Department of Pathology, Toranomon Hospital, Tokyo, Japan
}

\begin{abstract}
Bromocriptine, a potent D2-dopamine agonist, suppresses growth hormone $(\mathrm{GH})$ secretion in most patients with acromegaly and has been approved for the treatment of acromegaly. Here we report a patient with acromegaly who showed increased GH secretion after administration of bromocriptine. A 70-year-old man with acromegalic manifestation was admitted to our hospital because of a pituitary tumor invading to the right cavernous sinus detected by brain magnetic resonance imaging. Serum $\mathrm{GH}$ and insulin-like growth factor-I (IGF-I) levels were elevated in several occasions (GH: $15.0-51.7 \mathrm{ng} / \mathrm{mL}$, reference range: $<2.47$ $\mathrm{ng} / \mathrm{mL}$; and IGF-I: $776-856 \mathrm{ng} / \mathrm{mL}$, reference range: $57-175 \mathrm{ng} / \mathrm{mL}$ ). Effect of bromocriptine on serum $\mathrm{GH}$ levels was then studied because pre-operative treatment with a D2-dopamine agonist was planned in order to reduce the tumor size and serum GH levels before surgery. After oral administration of $2.5 \mathrm{mg}$ of bromocriptine, serum GH levels were unexpectedly increased from $30.7 \mathrm{ng} / \mathrm{mL}$ to $189 \mathrm{ng} / \mathrm{mL}$, despite the fact that the levels of prolactin (PRL) were decreased from $4.2 \mathrm{ng} / \mathrm{mL}$ to $0.6 \mathrm{ng} / \mathrm{mL}$. By contrast, serum GH levels were decreased by a somatostatin analogue, octreotide. Transsphenoidal surgery of the pituitary tumor was performed after treatment of octreotide. Histological analysis and immunohistochemistry revealed a GH-producing pituitary adenoma positive for D2-dopamine receptor. This case of acromegaly suggests that the preliminary test with a single administration of a short-acting D2-dopamine agonist, bromocriptine, is mandatory before the long-term therapy with a D2-dopamine agonist in patients with $\mathrm{GH}$-secreting pituitary tumors.
\end{abstract}

Keywords: acromegaly; bromocriptine; cabergoline; dopamine D2 receptor; growth hormone

Tohoku J. Exp. Med., 2014 October, 234 (2), 129-135. (C) 2014 Tohoku University Medical Press

\section{Introduction}

Acromegaly is a chronic disease caused by hypersecretion of growth hormone $(\mathrm{GH})$ and insulin-like growth factor-I (IGF-I), mostly due to the GH-secreting pituitary adenomas, and is known to have higher rate of mortality (Melmed 2006; Holdaway et al. 2008). Surgical removal of the tumor is the first-line treatment. Medical treatment, however, is commonly done for the patients who do not wish the surgery or who have not been cured by the surgery (Melmed et al. 2009). Medical treatment is also carried out before the surgery in order to shrink the tumor size (Bush and Vance 2008). Dopamine agonists, also known as stimulators of GH secretion in healthy subjects (Eddy et al. 1971), act as suppressors of GH secretion in patients with acromegaly and have been used for the medical therapy of acromegaly as well as prolactinoma (Thorner et al. 1975). Somatostatin receptor agonists (somatostatin analogues), such as octreotide and lanreotide, have been widely used to treat acromegaly during the past two decades, and dopamine agonists are not as effective as somatostatin receptor agonists (Melmed et al. 2009). However, dopamine agonists still play an important role for the medical therapy of acromegaly because of its less expensiveness and easier administration. Moreover, the role of dopamine agonists is being improved by the combination therapy with somatostatin analogue for patients who failed to normalize GH/ IGF-I by the somatostatin analogue monotherapy (Fløgstad et al. 1994).

Bromocriptine, a dopamine agonist, decreases serum

Received July 24, 2014; revised and accepted September 11, 2014. Published online September 25, 2014; doi: 10.1620/tjem.234.129.

Correspondence: Zenei Arihara, M.D., Ph.D., Department of Endocrinology and Metabolism, Sendai Medical Center, 2-8-8 Miyagino,

Miyagino-ku, Sendai, Miyagi 983-8520, Japan.

e-mail: arihara-zen@umin.ac.jp 
GH levels in most patients with acromegaly (Thorner et al. 1975). However, to the best of our knowledge, only one case report is available on a patient with acromegaly, in which serum GH levels were increased by bromocriptine (Shimatsu et al. 2000). Here, we report a patient with acromegaly who demonstrated a marked rise of serum GH levels in response to bromocriptine.

\section{Methods}

Endocrine tests

Hormone assays were performed by using following kits; serum GH was measured by immunoradiometric assay using GH "Daiichi" kit (TFB Inc., Tokyo, Japan), serum IGF-I by immunoradiometric assay using IGF-I IRMA "Daiichi” kit (TFB Inc.), and serum prolactin (PRL) by 2-site immunochemiluminescent assay using Chemilumi ACS-Prolactin kit (ADVIA Centaur, Tokyo, Japan).

Dynamic hormone tests were performed after overnight fasting. An indwelling catheter was inserted in a forearm vein at 8:00, and blood samples were collected before and after the injection of following stimulators: thyrotropin-releasing hormone (TRH) (TRH injection $0.5 \mathrm{mg}$ "Tanabe," Mitsubishi Tanabe Pharma Co., Osaka, Japan), luteinizing hormone-releasing hormone (LHRH) (LHRH injection 0.5 mg "Tanabe," Mitsubishi Tanabe Pharma Co.), corticotropin-releasing hormone (CRH) (hCRH injection $100 \mu \mathrm{g}$ "Tanabe," Mitsubishi Tanabe Pharma Co.), and metoclopramide, a D2-dopamine antagonist [intravenous injection (i.v.) of primperan $10 \mathrm{mg}$, Astellas, Tokyo, Japan]. Octreotide test and bromocriptine test were performed as follows. After basal blood samples were collected, octreotide [subcutaneous (s.c.) injection of sandostatin $50 \mu \mathrm{g}$, Novartis pharma Co., Tokyo, Japan] or bromocriptine (Parlodel Tablet $2.5 \mathrm{mg}$, Novartis pharma Co.) was administered, and blood samples were then collected at indicated times.

\section{Histological analysis}

Transsphenoidal surgery was performed at the Department of Hypothalamic and Pituitary surgery, Toranomon Hospital. Pathological diagnosis and immunohistochemistry of GH, adrenocorticotropic hormone (ACTH), PRL, luteinizing hormone (LH), folliclestimulating hormone (FSH), thyrotropin (TSH), Ki-67 (MIB-1) (a cell proliferation marker), cytokeratin (CAM5.2) (a marker for epithelial cells), Pit-1 (a pituitary specific transcription factor involved in the specification of the lactotrope, somatotrope, and thyrotrope phenotypes), somatostatin receptor 2 and 5 (SSTR2, SSTR5) and dopamine D2 receptor (D2R) were performed at the Department of Pathology, Toranomon hospital in Tokyo, Japan. Expression of SSTR2 and SSTR5 was studied because these two somatostatin receptor subtypes mediate the inhibitory action of somatostatin analogues on GH secretion (Shimon et al. 1997). D2R expression was studied because it is the predominant dopamine receptor subtype that mediates the action of dopamine agonists including bromocriptine on GH secretion (Ren et al. 2003; Neto et al. 2009).

The pituitary tumor was fixed in formalin. Paraffin-embedded sections were stained for hematoxylin and eosin (H.E.). Sections were also immunostained for pituitary hormones, Ki-67, CAM5.2, Pit-1 and cell membrane receptors by the avidin-biotin-peroxidase complex $(\mathrm{ABC})$ technique. Automated immunohistochemistry was performed by BenchMark GX (Ventana) with the following panel of antibodies: cytokeratin (CAM5.2; Becton Dickinson Bioscience, San Jose, CA, USA), ACTH (02A3; Dako, Carpinteria, CA, USA), FSH (C10; BioGenex, San Ramon, CA, USA), GH (54/9 2A2; BioGenex), LH (C93; Dako), PRL (polyclonal; Dako), and TSH (0042; Dako), Ki-67 (MIB-1; Dako), Pit-1 (BD Bioscience), SSTR2 (SS-800, Gramsch Lab., Germany), SSTR5 (SS-838, Gramsch Lab., Germany) and D2R (GTX-71745, Gene-Tex Inc., Irvine, CA, USA).

Informed consent was obtained from the patient concerning all the studies related to his case. This study was approved by the ethics committees of Sendai Medical Center and Toranomon hospital.

\section{Case Presentation}

A 70-year-old man was admitted to the Sendai Medical Center because of a pituitary tumor detected by brain magnetic resonance imaging (MRI), which was performed to examine the cause of forgetfulness. The pituitary adenoma was $15 \mathrm{~mm}$ in diameter and suspected to invade right cavernous sinus (Fig. 1). The patient was treated for diabetes mellitus with oral anti-hyperglycemic agents for several years. His height and body weight were $163.7 \mathrm{~cm}$ and 65.1 $\mathrm{kg}$, respectively. Moreover, he showed typical acromegalic
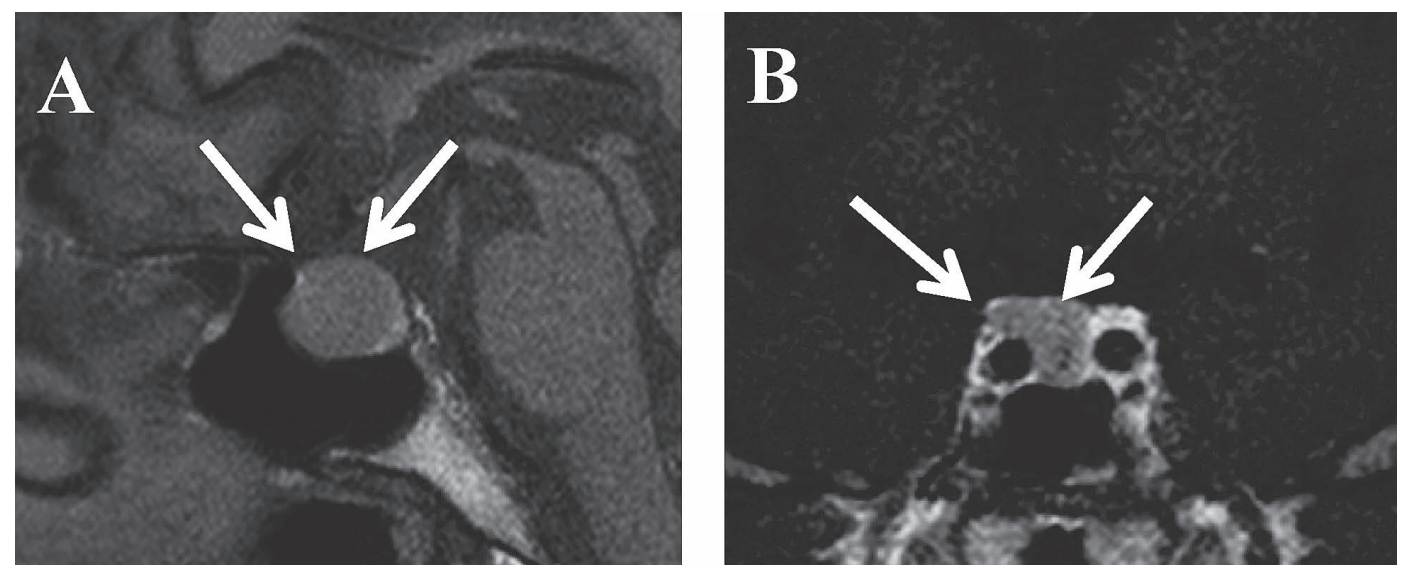

Fig. 1. Brain magnetic resonance imaging (MRI) of the patient. Shown are the sagittal section of T1 weighted image (A) and the coronal section of enhancing image (B). A less enhancing lesion $2.5 \mathrm{~cm}$ in diameter suggesting a pituitary adenoma (indicating by arrows) was observed in the right wing on T1-weighted enhancing MRI (B). 
disfigurement, such as countenance with forehead protrusion, enlarged tongue, thickened fingers and so on. Both serum GH and IGF-I levels were measured repeatedly and were greatly elevated $(\mathrm{GH}: 15.0-51.7 \mathrm{ng} / \mathrm{mL}$, reference range: $<2.47 \mathrm{ng} / \mathrm{mL}$; and IGF-I: $776-856 \mathrm{ng} / \mathrm{mL}$, reference range: $57-175 \mathrm{ng} / \mathrm{mL}$, respectively). Serum PRL level was $4.2 \mathrm{ng} / \mathrm{mL}$. Other pituitary hormones and their peripheral hormones were within normal ranges: TSH $1.216 \mu \mathrm{IU} / \mathrm{mL}$, free triiodothyronine (T3) $3.07 \mathrm{pg} / \mathrm{mL}$, free thyroxine (T4) $1.63 \mathrm{ng} / \mathrm{dL}$, ACTH $56.6 \mathrm{pg} / \mathrm{mL}$, cortisol $6.7 \mu \mathrm{g} / \mathrm{dL}, \mathrm{LH} 2.34$ $\mathrm{mIU} / \mathrm{mL}$, FSH $5.80 \mathrm{mIU} / \mathrm{mL}$, and testosterone $305.4 \mathrm{ng} /$ $\mathrm{mL}$.

TRH test caused the increase in serum GH from 15.0 to $37.4 \mathrm{ng} / \mathrm{mL}$, and serum PRL from 2.7 to $10.3 \mathrm{ng} / \mathrm{mL}$, respectively (Fig. 2A). Serum GH levels were elevated by LHRH test (from 31.1 to $55.0 \mathrm{ng} / \mathrm{mL}$ ) and CRH test (from 27.0 to $59.9 \mathrm{ng} / \mathrm{mL}$ ), respectively (data not shown). Serum GH levels were decreased by octreotide test at least up to 6 hours after injection $(51.7 \mathrm{ng} / \mathrm{mL}$ before the test, and 6.42 $\mathrm{ng} / \mathrm{mL}$ at nadir after 4 hours) (Fig. 2B).

Serum GH levels were greatly elevated by bromocriptine from $30.7 \mathrm{ng} / \mathrm{mL}$ to $145 \mathrm{ng} / \mathrm{mL}$ after 1 hour. After a transient decrease at 4 hours $(38.8 \mathrm{ng} / \mathrm{mL})$, serum GH levels continued to be higher than $100 \mathrm{ng} / \mathrm{mL}$ at least up to 24 hours (Fig. 2C). Serum PRL levels were decreased by bromocriptine from $4.2 \mathrm{ng} / \mathrm{mL}$ to the lower levels (below $1 \mathrm{ng}$ / $\mathrm{mL}$ from 4 hours to 24 hours with the minimum value of 0.6 $\mathrm{ng} / \mathrm{mL}$ found after 12 hours) (Fig. 2C). Serum GH and PRL levels were increased from $26.1 \mathrm{ng} / \mathrm{mL}$ to $36.7 \mathrm{ng} / \mathrm{mL}$ and from $4.2 \mathrm{ng} / \mathrm{mL}$ to $15.9 \mathrm{ng} / \mathrm{mL}$ to metoclopramide, respectively (Fig. 2D).

Octreotide was administrated in order to shrink the tumor. The patient was treated with octreotide (s.c. $50 \mu \mathrm{g}$ ) three times a day for initial three days and with octreotide (s.c. $100 \mu \mathrm{g}$ ) three times a day for next four days, followed by intramuscular injection (i.m.) of octreotide LAR (20 mg) two times for every four weeks. He then underwent surgical treatment of the pituitary tumor. Soft and white tumor tissue was completely removed by transsphenoidal surgery. Both serum IGF-I and GH levels were restored to normal. Serum GH level was decreased to $0.13 \mathrm{ng} / \mathrm{mL}$ by $75 \mathrm{~g}$ oral glucose tolerance test (OGTT) after the surgery, indicating that the pituitary tumor was successfully removed.

Histopathological examinations using H.E. staining demonstrated an eosinophilic adenoma (Fig. 3A). Immunohistochemistry demonstrated diffuse, strongly positive immunostaining for GH (Fig. 3B) and negative immunostaining for PRL (Fig. 3C), TSH, ACTH, LH and FSHmono (data not shown). MIB-1/Ki-67 labeling index was $0.3 \%$, and CAM5.2 staining showed a characteristic perinuclear dot-like pattern (data not shown). Pit-1 transcription factor was positive (data not shown). Immunostaining of membrane receptors showed positive for SSTR2 (Fig. 3D), SSTR5 (Fig. 3E) and D2R in tumor cells (Fig. 3F).

\section{Discussion}

The present case of acromegaly showed great increases of serum GH levels by bromocriptine. After the initial rise at one hour, sustained elevated levels of serum GH over $100 \mathrm{ng} / \mathrm{mL}$ were observed from 6 hours, and at least up to 24 hours after bromocriptine administration. By contrast, the elevation of serum GH levels over $100 \mathrm{ng} / \mathrm{mL}$ was not observed in other GH stimulating tests, including TRH, $\mathrm{CRH}$ and LHRH tests. The rise of serum GH after bromocriptine was, therefore, unlikely to be a non-specific reaction or an accidental phenomenon.

Dopamine agonists inhibit the release of $\mathrm{GH}$ from human fetal pituitary cells and from most GH adenoma cells in vitro (Ren et al. 2003). The D2R belongs to the Gi/ocoupled family of receptors and inhibits pituitary cell proliferation, transformation, and hormone production (Missale et al. 1998). The inhibition of PRL secretion mediated by $\mathrm{D} 2 \mathrm{R}$ leads to major therapeutic application in the treatment of hyperprolactinemia caused by PRL-secreting tumors (Missale et al. 1998). D2R is the predominant dopamine receptor subtype that is expressed in both normal pituitaries and somatotropinomas (Neto et al. 2009). Moreover, D2R and somatostatin receptor subtypes interact physically through hetero-oligomerization to create a novel receptor with enhanced functional activity (Rocheville et al. 2000; Ren et al. 2003). Ren et al. (2003) showed a functional interaction between D2R and SSTR2 for regulating GH and PRL secretion on pituitary cells including adenoma cells, and D2R appeared to have a dominant role over SSTR2 in regulating their secretion.

In contrast to the inhibition of the GH secretion by dopamine agonists in most acromegalic patients in vivo, dopamine agonists evoked GH secretion from normal subjects via central mechanism, possibly due to growth hormone-releasing hormone (GHRH) and/or somatostatin. GH secretion in the pituitary is mainly regulated by GHRH and somatostatin, both of which are derived from the neurosecretory nuclei of the hypothalamus and are controlled by dopamine (Tannenbaum and Ling 1984; Arce et al. 1991; Müller et al. 1999). García-Tornadú et al. (2006) showed that a loss of dopamine signaling via the hypothalamic D2R caused the reduced release of GHRH from hypophysiotropic neurons in D2R knockout mice, suggesting that hypothalamic D2R plays an important role in GHRH secretion. It was reported that endogenous GHRH was required for the GH response to pharmacologic stimuli, such as L-dopa, in healthy subjects (Jaffe et al. 1996). In patients with acromegaly, the hypothalamic GHRH is suppressed by negative feedback due to hypersecretion of GH and IGF-I (Abe et al. 1983; Jaffe et al. 1998). Therefore, D2R agonists might be a therapeutic application in patients with acromegaly.

In the present case, metoclopramide, a D2-dopamine antagonist caused only a modest increase in serum GH levels (less than a 1.5 fold increase compared to the basal level), whereas bromocriptine, a D2-dopamine agonist, 

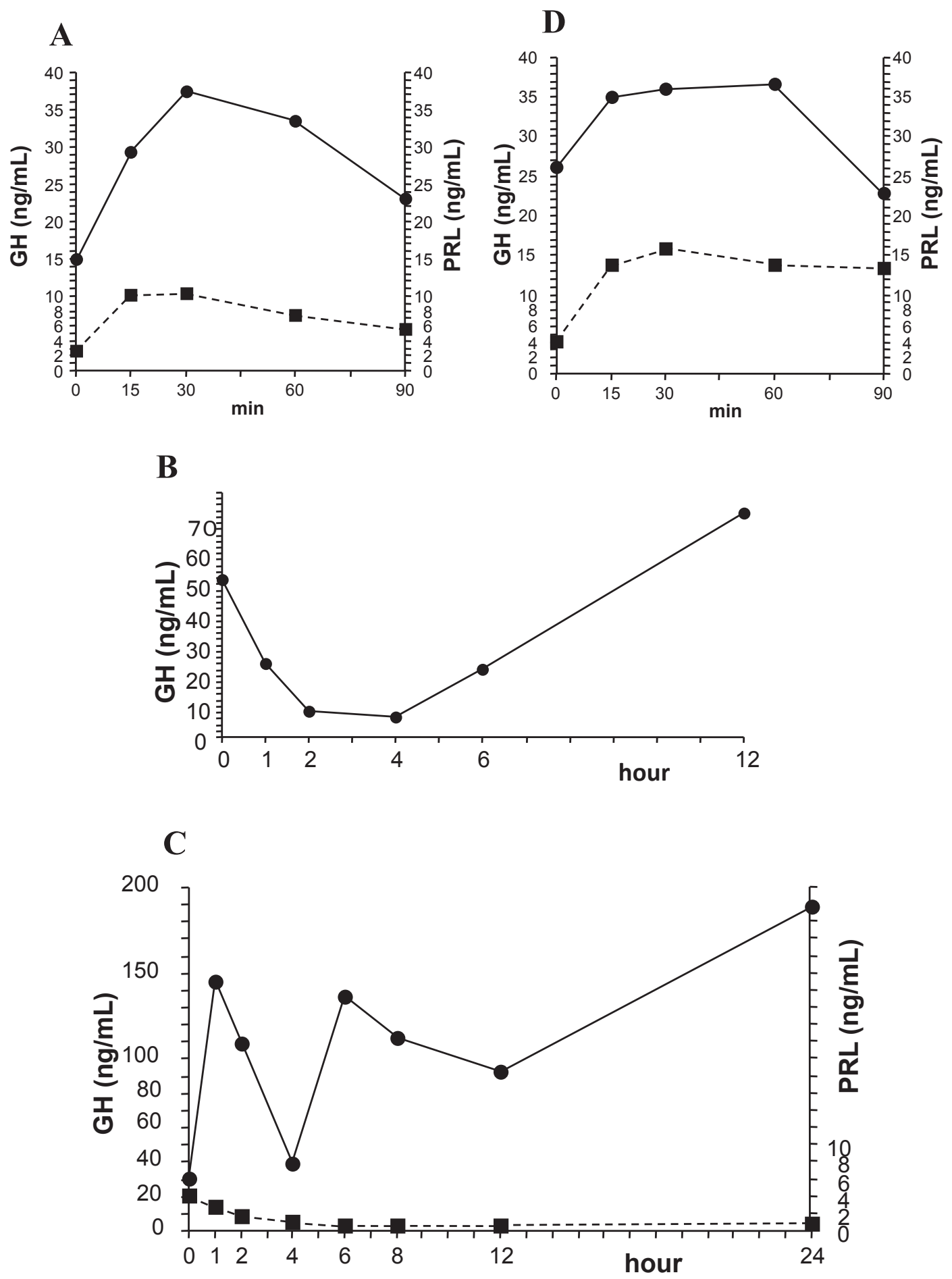

Fig. 2. Results in dynamic endocrine tests.

Changes in serum growth hormone (GH) and prolactin (PRL) levels in thyrotropin-releasing hormone (TRH) test (A), octreotide test (B) and bromocriptine test (C) and metoclopramide test (D). Blood samples were collected at indicated times before and after the administration of TRH ( $0.5 \mathrm{mg}$, i.v.), octreotide $(50 \mu \mathrm{g}$, s.c.), bromocriptine $(2.5 \mathrm{mg}$, per os) or metoclopramide (10 mg, i.v.), and serum GH and PRL levels were measured. Closed circle and solid line: $\mathrm{GH}$; closed square and dotted line: PRL.

increased serum GH levels greatly. Arce et al. (1991) showed that blockade of the central dopaminergic pathway by metoclopramide in 10 normal human subjects increased GHRH-induced GH secretion, possibly by inhibiting the hypothalamic release of somatostatin. The modest increase in serum GH by metoclopramide in the present case may be caused by the blockade of the central dopaminergic pathway as well as its antagonistic action on D2R in the pitu- 

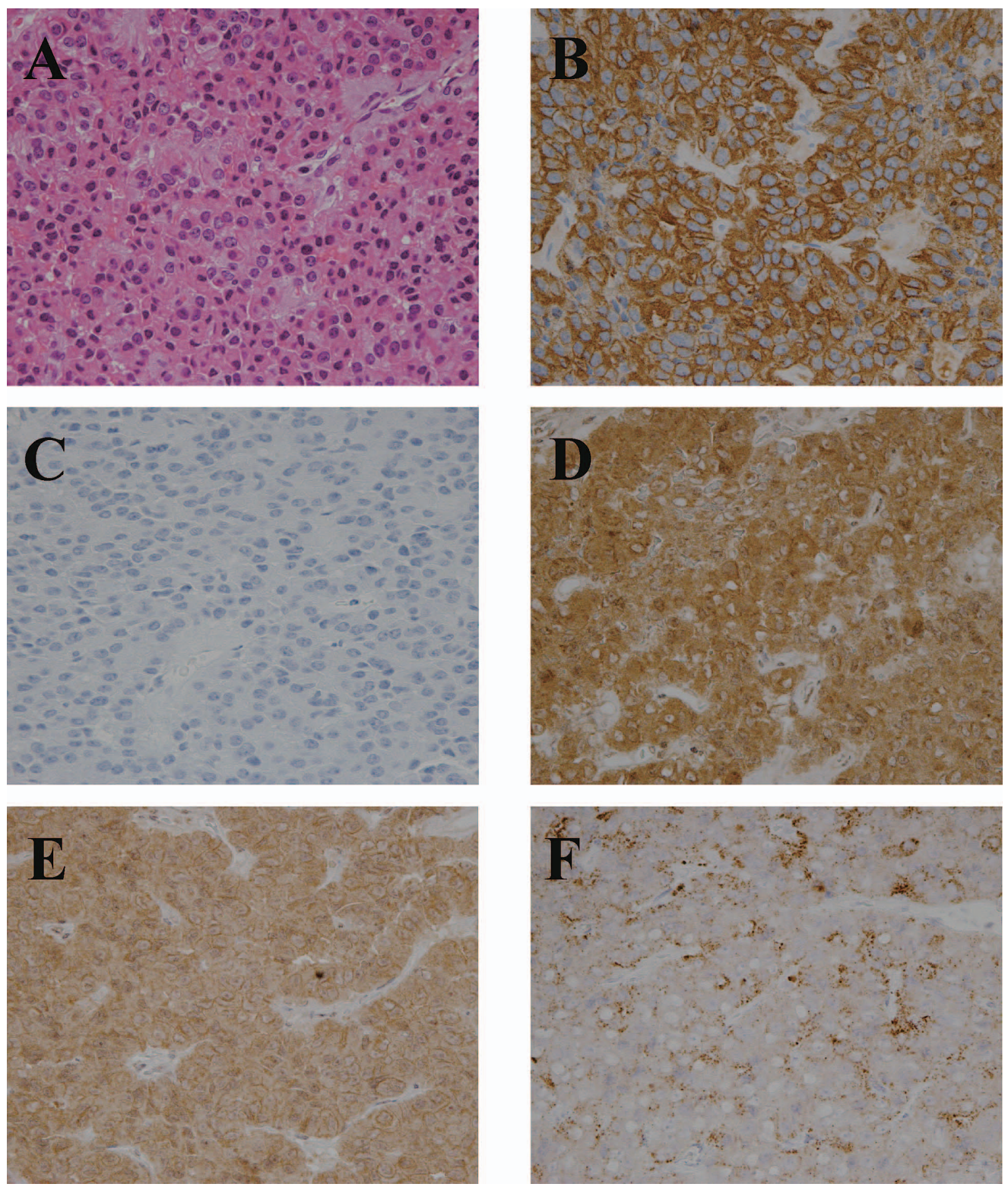

Fig. 3. Immunohistochemistry of anterior pituitary hormones and cell membrane receptors in the adenoma.

Hematoxylin and eosin (H.E.) staining (A) and immunohistochemistry of GH (B), PRL (C), somatostatin receptor 2 (SSTR2) (D), somatostatin receptor 5 (SSTR5) (E), and dopamine D2 receptor (D2R) (F). Expression of SSTR2 and SSTR5 was studied because these two somatostatin receptor subtypes mediate the inhibitory action of somatostatin analogues on GH secretion. Expression of D2R was studied because it mediates the action of dopamine agonists including bromocriptine on GH secretion. Immunohistochemistry showed positive immunostaining for GH (B), negative for PRL (C), positive for SSTR2 (D), positive for SSTR5 (E) and positive for D2R (F).

itary adenoma.

One possible explanation for serum GH response to bromocriptine is the presence of pituitary hyperplasia either due to hypothalamic or to ectopic hypersecretion of GHRH. The findings of MRI scan of the pituitary and the pathological examination of the surgical specimen, however, did not support this possibility in this case. Moreover, the presence of an ectopic GHRH producing tumor was not observed in the whole body scan of computed tomography (CT) (data not shown).

Immunohistochemistry revealed positive immunos- taining for SSTR2, SSTR5 and D2R in the tumor tissue of pituitary adenoma, similarly to ordinary somatotroph adenomas. The presence of altered intracellular signaling may explain for the serum GH response to bromocriptine in the present case. Vallar et al. (1987) found a profoundly altered Gs protein in a group of human GH-secreting pituitary adenomas, characterized by high secretory activity and intracellular cyclic AMP levels, and suggested that the alteration of Gs could be the direct cause of the high secretory activity of the adenomas. Moreover, Ballaré et al. (1997) showed a low expression of proteins of the Gi subfamily in human 
pituitary adenomas in contrast to Gs $\alpha$ protein, which was markedly positive in these adenomas. Decreased expression of D2R and Gai2 protein was reported in bromocriptine resistant prolactinomas (Pellegrini et al. 1989; Caccavelli et al. 1996). The GH response to bromocriptine in the present case may be explained by a decreased expression of $\mathrm{Gi}$ protein in the adenoma and the resulting decreased inhibitory signaling on GH secretion, which need further investigations.

Furthermore, the administration of bromocriptine might elicit GHRH action on the adenoma cells by certain central mechanism. In addition, GHRH might have a predominant action on the $\mathrm{GH}$ secretion from the pituitary adenoma over the D2R-mediated suppressive action in the present case. Further studies, including central effects of D2R agonist on GHRH secretion and a possible involvement of ghrelin (Avram et al. 2005), are required to clarify the reason(s) for increased serum GH levels in response to bromocriptine. In contrast to the bromocriptine effect, serum GH levels were suppressed by a somatostatin analogue, octreotide in the present case. In this regard, different $\mathrm{G}$ proteins may be involved in the coupling of dopamine and somatostatin receptors with adenylate cyclase (Musset et al. 1990).

This case has an important implication for the medical therapy for acromegaly. Dopamine agonists play a mere adjunctive role in the treatment of acromegaly whereas they play the main role in the treatment for prolactinoma. This case might provide important clues on the medical treatment for acromegaly. For example, treatment of D2R agonist combined with GHRH receptor antagonist, if a GHRH receptor blocker is available in future, might be a more effective medical therapy. Furthermore, the present report suggests that the preliminary test with a single administration of short-acting bromocriptine is required before the therapy with long-term D2-dopamine agonists, such as cabergoline.

\section{Conflict of Interest}

The authors declare no conflict of interest.

\section{References}

Abe, H., Molitch, M.E., Van Wyk, J.J. \& Underwood, L.E. (1983) Human growth hormone and somatomedin $\mathrm{C}$ suppress the spontaneous release of growth hormone in unanesthetized rats. Endocrinology, 113, 1319-1324.

Arce, V., Lima, L., Lois, N., Rodríguez, A., Díaz, M.J., Tresguerres, J.A. \& Devesa, J. (1991) Role of central dopaminergic pathways in the neural control of growth hormone secretion in normal men: studies with metoclopramide. Neuroendocrinology, 53, 143-149.

Avram, A.M., Jaffe, C.A., Symons, K.V. \& Barkan, A.L. (2005) Endogenous circulating ghrelin does not mediate growth hormone rhythmicity or response to fasting. J. Clin. Endocrinol. Metab., 90, 2982-2987.

Ballaré, E., Mantovani, S., Bassetti, M., Lania, A. \& Spada, A. (1997) Immunodetection of G proteins in human pituitary adenomas: evidence for a low expression of proteins of the Gi subfamily. Eur. J. Endocrinol., 137, 482-489.

Bush, Z.M. \& Vance, M.L. (2008) Management of acromegaly: is there a role for primary medical therapy? Rev. Endocr. Metab. Disord., 9, 83-94.

Caccavelli, L., Morange-Ramos, I., Kordon, C., Jaquet, P. \& Enjalbert, A. (1996) Alteration of G alpha subunits mRNA levels in bromocriptine resistant prolactinomas. J. Neuroendocrinol., 8, 737-746.

Eddy, R.L., Jones, A.L., Chakmakjian, Z.H. \& Silverthorne, M.C. (1971) Effect of levodopa (L-DOPA) on human hypophyseal tropic hormone release. J. Clin. Endocrinol. Metab., 33, 709-712.

Fløgstad, A.K., Halse, J., Grass, P., Abisch, E., Djøseland, O., Kutz, K., Bodd, E. \& Jervell, J. (1994) A comparison of octreotide, bromocriptine, or a combination of both drugs in acromegaly. J. Clin. Endocrinol. Metab., 79, 461-465.

García-Tornadú, I., Rubinstein, M., Gaylinn, B.D., Hill, D., Arany, E., Low, M.J., Díaz-Torga, G. \& Becu-Villalobos, D. (2006) $\mathrm{GH}$ in the dwarf dopaminergic D2 receptor knockout mouse: somatotrope population, GH release, and responsiveness to GH-releasing factors and somatostatin. J. Endocrinol., 190, 611-619.

Holdaway, I.M., Bolland, M.J. \& Gamble, G.D. (2008) A metaanalysis of the effect of lowering serum levels of GH and IGF-I on mortality in acromegaly. Eur. J. Endocrinol., 159, 89-95.

Jaffe, C.A., DeMott-Friberg, R. \& Barkan, A.L. (1996) Endogenous growth hormone $(\mathrm{GH})$-releasing hormone is required for $\mathrm{GH}$ responses to pharmacological stimuli. J. Clin. Invest., 97, 934-940.

Jaffe, C.A., Ocampo-Lim, B., Guo, W., Krueger, K., Sugahara, I., DeMott-Friberg, R., Bermann, M. \& Barkan, A.L. (1998) Regulatory mechanisms of growth hormone secretion are sexually dimorphic. J. Clin. Invest., 102, 153-164.

Melmed, S. (2006) Medical progress. Acromegaly. N. Engl. J. Med., 355, 2558-2573.

Melmed, S., Colao, A., Barkan, A., Molitch, M., Grossman, A.B., Kleinberg, D., Clemmons, D., Chanson, P., Laws, E., Schlechte, J., Vance, M.L., Ho, K. \& Giustina, A. (2009) Guidelines for acromegaly management: an update. J. Clin. Endocrinol. Metab., 94, 1509-1517.

Missale, C., Nash, S.R., Robinson, S.W., Jaber, M. \& Caron, M.G. (1998) Dopamine receptors: from structure to function. Physiol. Rev., 78, 189-225.

Müller, E.E., Locatelli, V. \& Cocchi, D. (1999) Neuroendocrine control of growth hormone secretion. Physiol. Rev., 79, 511-607.

Musset, F., Bertrand, P., Kordon, C. \& Enjalbert, A. (1990) Differential coupling with pertussis toxin-sensitive $G$ proteins of dopamine and somatostatin receptors involved in regulation of adenohypophyseal secretion. Mol. Cell. Endocrinol., 73, 1-10.

Neto, L.V., Machado, E. de O., Luque, R.M., Taboada, G.F., Marcondes, J.B., Chimelli, L.M., Quintella, L.P., Niemeyer, P. Jr., de Carvalho, D.P., Kineman, R.D. \& Gadelha, M.R. (2009) Expression analysis of dopamine receptor subtypes in normal human pituitaries, nonfunctioning pituitary adenomas and somatotropinomas, and the association between dopamine and somatostatin receptors with clinical response to octreotideLAR in acromegaly. J. Clin. Endocrinol. Metab., 94, 19311937.

Pellegrini, I., Rasolonjanahary, R., Gunz, G., Bertrand, P., Delivet, S., Jedynak, C.P., Kordon, C., Peillon, F., Jaquet, P. \& Enjalbert, A. (1989) Resistance to bromocriptine in prolactinomas. J. Clin. Endocrinol. Metab., 69, 500-509.

Ren, S.G., Kim, S., Taylor, J., Dong, J., Moreau, J.P., Culler, M.D. \& Melmed, S. (2003) Suppression of rat and human growth hormone and prolactin secretion by a novel somatostatin/ dopaminergic chimeric ligand. J. Clin. Endocrinol. Metab., 88, 5414-5421. 
Rocheville, M., Lange, D.C., Kumar, U., Patel, S.C., Patel, R.C. \& Patel, Y.C. (2000) Receptors for dopamine and somatostatin: formation of hetero-oligomers with enhanced functional activity. Science, 288, 154-157.

Shimatsu, A., Murabe, H., Nakamura, Y. \& Usui, T. (2000) Rebound hypersecretion of GH following octreotide withdrawal due to liver dysfunction in an acromegalic patient. Endocr. J., 47, 635-638.

Shimon, I., Yan, X., Taylor, J.E., Weiss, M.H., Culler, M.D. \& Melmed, S. (1997) Somatostatin receptor (SSTR) subtypeselective analogues differentially suppress in vitro growth hormone and prolactin in human pituitary adenomas. Novel potential therapy for functional pituitary tumors. J. Clin.
Invest., 100, 2386-2392.

Tannenbaum, G.S. \& Ling, N. (1984) The interrelationship of growth hormone $(\mathrm{GH})$-releasing factor and somatostatin in generation of the ultradian rhythm of GH secretion. Endocrinology, 115, 1952-1957.

Thorner, M.O., Chait, A., Aitken, M., Benker, G., Bloom, S.R., Mortimer, C.H., Sanders, P., Mason, A.S. \& Besser, G.M. (1975) Bromocriptine treatment of acromegaly. Br. Med. J., 1, 299-303.

Vallar, L., Spada, A. \& Giannattasio, G. (1987) Altered Gs and adenylate cyclase activity in human GH-secreting pituitary adenomas. Nature, 330, 566-568. 